Predrag Vuković ${ }^{1}$

Institute of Agricultural Economics, Belgrade

Drago Cvijanović ${ }^{2}$

University of Kragujevac,

Faculty of Tourism and Hospitality

Branko Mihailović ${ }^{3}$

Institute of Agricultural Economics, Belgrade
SCIENTIFIC REVIEW ARTICLE doi:10.5937/ekonomika1504069V

Received: October 20, 2015

Accepted: November 26, 2015

\title{
PERSPECTIVES FOR DEVELOPMENT OF RURAL TOURISM IN THE AREA OF NOVI SAD ${ }^{4}$
}

\begin{abstract}
Novi Sad is the second largest city in the Republic of Serbia and the administrative center of the Autonomous Province of Vojvodina. On its surroundings there is a perspective area for development rural tourism. So far there have been launched some initiatives to develop rural tourism. These initiatives in conjunction with other elements of tourist supply can increase tourist offer. Rural tourism development should be based on the rich pension and out-of-pension tourist offer. What appears as a decisive factor in gaining competitive advantage in the tourism market is the opportunity to develop a wide variety of up-market tourist attractions. Presence of natural and human (anthropogenic) sources must be a marketing and management leading to achieve certain results. In this regard is the important role of the Tourism Organization of Novi Sad, local administrations and the private sector. The article emphasizes importance of public-private partnerships and management approach as a basis for gaining competitive advantage at the tourist market. Also, the paperwork provides an overview of resources that represent the potential for future rural tourism development. Expectations are that the complementary development with other forms of tourism, rural tourism will contribute to the overall economic development of this area.
\end{abstract}

Key words: rural tourism, destinations, agriculture, resources, sustainable development

JEL classification: $Q 2, Q 12, R 58$

\footnotetext{
${ }^{1}$ predrag_v@iep.bg.ac.rs

2 dvcmmv@gmail.com

${ }^{3}$ brankomih@neobee.net

${ }^{4}$ This paper work is result of the project No. 46006 - III „Sustainable agriculture and rural development in function realizing strategic goals of the Republic of Serbia in framework of Danube region", financing by the Ministry of Education and Science of the Republic of Serbia in period $2011-2014$.
} 


\title{
ПЕРСПЕКТИВЕ РАЗВОЈА РУРАЛНОГ ТУРИЗМА НА ПОДРУЧЈУ ГРАДА НОВОГ САДА
}

\begin{abstract}
Абстракт
Нови Сад је други по величини град у Републици Србији и административни је иентар АП Војводине. У юеговој околини постоји перспективан простор за развој сеоског туризма. До сада су покренуте неке иницијативе за развој руралног туризма. Ове инииијативе у комбинацији са другим елементима туристичке понуде могу да повећају туристичку понуду и атрактивност ове дестиначије. Развој руралног туризма треба да се заснива на богатој пансионској и ван пансионској туристичкој понуди. Оно што се појављује као одлучујући фактор у стицању конкурентске предности на туристичком тржишту је прилика да се развије цирок спектар различитих ван пансионских туристичких активности чиме се повећава атрактивност ове дестинације. Присуство природних и друштвених (антропогених) ресурса мора бити маркетиншки и менацерски вођено како би пружило одговарајуће резултате. У том смислу важна је улога Туристичке организаиије Новог Сада, локалних управа и приватног сектора. У раду се истиче значај јавноприватног партнерства и менаимерски приступ као основа за стицање конкурентске предности на туристичком тржсишт. Такође, даје се преглед ресурса који представљају потеничјал за развој руралне туристичке понуде. Очекиваьа су да би комплементаран развој са другим видовима туризма, омогућио руралном туризму да допринесе укупном економском развоју овог подручја.
\end{abstract}

Кључне речи: сеоски туризам, дестинације, пољопривреде, ресурса, одрживи развој

\section{Introduction}

Novi Sad is the capital of the Autonomous Province of Vojvodina and the second largest city in the Republic of Serbia. Located on the north part of Serbia, with its whole natural and geographic position belongs to the Pannonian plain. Rich natural and geographic resources located in Novi Sad surrounding makes that it is possible to invest in rural areas and further develop them. An important role has to be given to the plan of the sustainable tourist development which is the basic point and condition of any further planning and activity in rural tourism.

The aim of paper work is to research possibilities for sustainable tourist development of rural areas in the Municipality of Novi Sad and pay attention to the influence of rural tourism and total social growth exerted on the ecological processes and the quality of the environment itself. 


\section{Material and method}

The subject of the article is the status and conditions for the development of rural tourism in the area of Novi Sad. The aim is to point out the potential strategic directions for the future development of the tourist destination Novi Sad in the context of sustainable development. In this way, obviously great potential for further development of tourism would be a practical sense realized. Former policy undifferentiated marketing did not give results. The strategy of market focus, integrated marketing, with a clear specifying tourism aspects, with the consistent implementation of the basis on which should insist in future development. Methods that used in this paper are: inductive-deductive method, qualitative method, comparative method.

\section{Result and discussion}

The fast scientific, technical and technological progress that was immanent to all industrial revolutions brought about an enormous use of all natural resources. The availability of the resources, as well as all the factors of production, taking into account such a model of an accelerated development, has been slowly reduced by time. This is particularly so for the whole mankind.

The model of rapid industrial development itself has exhausted the main generic forces and factors and has brought about serious disturbances of the natural environment, i.e. its ecological pollution. The term sustainable development appeared at the beginning of the eighties in the $20^{\text {th }}$ century. It took into account the establishment of positive relations between the human needs for a better quality of life, the economic development and the disturbed environment.

In the Republic of Serbia $10 \%$ of the territory is protected by the Law. Ecological Network for Serbia now contains 101 ecologically important areas, which are deposited on a proposal of the Bureau, i.e. the Ministry of Agriculture and Environmental protection.

Novi Sad as a tourist destination has fairly well preserved natural environment. Fruška Gora should be mentioned here, in the first place. In 1961 it has been proclaimed a national park. Later, it has been recognized as a territory with special natural, cultural and historical values and sights. Consequently, by adopting a corresponding law and space plan it has become known. It belongs to one of five national parks in Serbia. There are 25400 ha protected by the Government.

As a specially highly preserved, in terms of ecology, the areas in the Municipality of Novi Sad, which are highly valued for its further sustainable development, are as follows:

1) Natural Park Fruška Gora.

2) Protected natural assets - Nature park (Begečka jama, Tikvara, Panonija)

3) Protected natural assets - Nature reserve (Kovilj - Petrovaradin swampy). It has been proclaimed some 71 nature reserve in Serbia, so far, including total area of 84000 hectares. There are special nature reserves in an area of more than 100 hectares.

4) International important bird areas - IBA (Marsh of Kovilje, Fruška gora, The Danubian lumber section). Serbia has 35 regions which are important bird areas 
and which satisfy tstrict requirements of "IBA criteria", respecting all the rules and regulations established by the organisation "Bird Life International".

All these areas testify that there is a very high quality of a preserved ecological system, i.e. the natural environment on the whole and high level maintenance and respecting of all ecological standards. If further tourist development is required then all the elements for preservation of these standards should be considered.

It is indisputable that the anthropological resources of Novi Sad have high quality and rich in their historical background. Keeping in mind that, at one side, the problem of tourism has not been paid great attention to, so far (or the attention it has desserved) as well as "so and so" preserved anthropological resource, on the other side, as an imperative for further planning of its tourist development, there should be taken into account the maintenance of all the segments of its rich cultural and historical background.

This is the condition for its further tourist development. This means certain investments in them for further usage.

The division of the cultural and historical background could be made in the following way:

\section{Cultural and historical entities.}

- $\quad$ Town centres: Novi Sad, Petrovaradin, Sremski Karlovci, Sremska Kamenica.

- $\quad$ Fruška gora with its monasteries and other sights

- Great number of villages on whole territory of Municipality

- Farms "ranch"- salaši as a specific feature of Vojvodina region.

\section{Important places and works with monument and artistic features.}

Particular places in all of the above mentioned environment entities with an important cultural and historical background are numerous and call for a special attention. Many places have a very important role, not only in history of Serbia, but Europe, too. Many of them have the characteristic of the cultural monuments with rare artistic, historical and aesthetic values.

\section{Folklore background.}

The cultural and ethnic wealth of many nations and nationalities which coexisted for centuries in the region of Vojvodina is immeasurable. It can be the topic of tourism special interest from the Western Europe, America, Japan, etc. Ethnic contents, as the investigations undertaken have already shown, look like something exotic to the tourist from these countries.

\section{Manifestation values.}

Various manifestations, typical of Vojvodina and the customs of its nations and nationalities (its inhabitants) do and may do enrich the cultural contents of numerous rural areas.

\section{Archeological findings.}

The localities on Fruška gora, Petrovaradin, etc. speak about the tempestuous history of the people living here in the previous centuries.

Thanks to the large number of natural and social resources, there are great opportunities for the development of special interest tourism. In this sense there is opportunity for complementary development of rural tourism with a tourism of special interests.

\section{Tourism on the Danube River}

The Danube is second largest European river waterway. In terms of transport and trade 
it has become even more important by digging the Rajna-Majna-Danube channel. With all its length it is a navigable river, $588 \mathrm{~km}$ or $13.5 \%$ of its total waterway. Follow, what makes it possible to use its natural and geographical advantage, keeping in mind the sustainable development of the environment.

The development of the nautical tourism accompanied by all sport program and recreation on water etc., has become the natural outcome of the above mentioned. There are many beaches on the river banks that make it possible to develop restaurant management as well as other accompanying services, during the stay on the river. Also, it is possible to develop ethno village near the river which can attract attention of cruising tourists. In this village is possible to supply all characteristic rural products to tourists.

\section{Agritourism supply}

Thanks to the natural ecological and environmental characteristics, the rural areas are very interesting and promising ones for the development of agritourism. Adequately built up cottages for rest in the countryside, characterized by silence and tranquility, are real oases for the people living in highly urban industrial centers, widespread in domestic and foreign markets. In the past, the development of this form of tourism has been declaratively supported, but, recently some new ideas have been recovered. Thus, in the course of 2004, aiming at promoting Serbia as a transit destination on the way to the Olympic games in Athens, two typical farms (ranch - "salash") were built. They had all the characteristics of a life and customs in the region of Vojvodina (typical farms No. 84 and 137). They were published in the tourist map of Serbia. Numerous villages in Vojvodina are the base for further planning keeping in mind new tendencies in the west (the so-called "return to the origins") the idea of healthy food, old customs and crafts and an ever growing popularity of typical ethno-contents such as the music, folklore, naive painting, etc.

\section{Hunting and fishing}

Vojvodina has a long tradition in hunting, but it also cares for its fauna. In the past twenty-five years, the well-known hunting ground have unfortunately been neglected, such as: Plavna, Morovoć, Karakuša, Karadjordjevo, Sombor woods, Apatinski bogland, Desert Delibato Subota, and probably the largest hunting area of Fruška gora.

Once, Fruška gora used to be the highest level hunting area for the diplomats because of its natural beauties, it offers the ideal conditions for the settlement of game, especially wild boars, roe deer, small game. With relevant laws and regulations watching out for the sustainable development and respecting all ecological standards, with corresponding investments in this area, Fruška gora may become a great tourist potential.

\section{Photo safari}

The diverse animal and vegetable world of Vojvodina, from orchard to conifers, from roe deer and rabbits to deer and eagles, make it an interesting region for the tourist who want such things. The most different plant species prove that the nature is intact, where all nature lovers may enjoy themselves. Vojvodina owns rich domiciles of birds, with very rare species. Some of them are: black stork (Ciconia nigra), swan (Cygnys olor), white-tailed eagle (Haliaeetys albicilla), black kite (Milvys nigranis), night heron (hycticorax), great white heron (Egretta alba) and small white heron (Egretta garzetta).

\section{Monastery tourism}

Fruška gora, with its seventeen monasteries, has a great potential for the development of this form of tourism. The monasteries there are the cultural, historical and religious precious stone, often called "second Serbian Holy Mountain - Serbian Mount Athos". Due to long-time 
non-investment and neglect of them, these monasteries, such as: Beočin, Basenovo, Divša, Gregateg, Jazak, Krušedol, Kuvezdin, Mala Remeta, Velika Remeta, Novo Hopovo, Staro Hopovo, Petkovica, Rakovac, Privina glava, Šišatovac, Panek and Ravanica, which have been burned and devastated in course of their history, should be adapted and reconstructed. This should be the priority task of the government both in terms of culture and religion.

\section{Wine tourism}

The districts characteristic for the upbringing of grapevine and wine production, record significant income from numerous tourists who, at the time of grape picking, come to attend many wine festivals. The income is acquired both regarding the sale, i.e. the wine consumption, as well as regarding the expenses that tourists have during their stay at a given destination. Sremski Karlovci has an important potential for the development of this form of tourism. In Vienna they have protected name of rose wine well-known as "Karlovački tovjan" and among all Srem vines, the wines from Karlovac, which are made of raisins have acquired a good reputation (especially black vines). Black grapes are used to make famous "Karlovački ausbruch (i.e. Juice flowing from the grapes themselves), "Cipar wine", "Tropf Vermut", "Plenaš" and ordinary vermouth.

The events of the traditional grapes, picking holding in Sremski Karlovci in autumn every year. This is followed by the other festivities there. Quality wines from this region have been awarded many "flattering" rewards at many competitions held worldwide.

The production of many wine brands for which there are nature resources available and wine cellars, too, may attract a great number of tourists, both the domestic and the foreign ones.

Keeping in mind the tendencies of the tourist market to exceed the idea of mass tourism, in recent years, it has been recorded that the interest for special needs tourism has been increased. By the end of the last decade, the model of the rural development (CAP) was promoted it assumed a multifunctional character of the European agriculture and its role in the development of the economy and the whole society. Agriculture, as a primary economic branch, has far-reaching interest for complementary cooperation with all sectors of economy. The same refers to the tourism.

One of the characteristics of the modern tourist market is that the unique product are highly esteemed and that the tourists nowadays tend to run away from the uniformity that the globalization process has offered them. In this sense, the component part of the tourist offer is more frequently - local, regional or national. The role of rural house-holdings has become ever stronger and area of Municipality of Novi Sad has very respectable resources there.

The perspectives would be, as follows:

1. Informing the tourist about the tradition and the customs of the nations and nationalities, particularly in the villages representing the multiethnic communities and enriching them. This brings about wide creativity in making various programs and activities.

2. Gastronomy, i.e. the production of special local food and preparing of the "healthy food" or the organic food production (officially called so). The idea has been very popular in highly urbanized countries; recently it may be the contents of caterer and other manifestations with cookery as a subject matter.

3. Getting to know the folklore and "dances" of all nations and nationalities. It's quite logic, then to organize many manifestations that could fulfill the cultural program in the course of a year, in rural areas. 
4. Getting to know old crafts and tools. During a long historical development of human society there were many crafts and tools which once used to have an important role in the rural households. Unfortunately, they had been forgotten and abandoned long time ago. They are especially interesting for the tourist of highly developed urbanized industrial countries and significantly enrich the tourist offer. However, these crafts may survive by common efforts only. Many organizations which make business or plan to do it in the rural areas, have a task of encouraging the local population, to organize them and help them supply raw material to dispose of goods and make an additional income for their families.

5. Folk arts and crafts. Rich multiethnic conditions make it possible for enriched and various folk arts and crafts, which may be very attractive to the tourists almost every region can boast with its typical product that appeared as a work of diligent hands of the local residents. Folk arts and crafts is the privilege of the residents of different rural areas, who invest their time, skill and talent. The products of folk arts and crafts may become basic point for the development of a special branch of the economy in rural areas.

6. Cultural and sports performances. They enrich and improve the variety of the tourist offer. An important role in promoting some of the above offers might be given to the private sector, i.e. a small business.

Partially made tourist programs should be supported, particularly fiscally, but also support in sale, since both of them could enrich the forms of non-pensions offers. This would also contribute to an efficient presentation and market valorization of the anthropological and other resources. This would further contribute to additional employment in the private sector without any significant initial investments. Elaboration of a high-quality program of stay in the village should not be left to the local resource fullness. It should be a serious topic of analysis if the development and the effects of this form of tourism are expected. The quality of the services offered, as many investigations carried out confirm, is one of the decisive factors that the tourists quote when they grade their stay in a certain tourist destination. This gives a chance for the residents in these regions, to expert their creative work.

\section{Conclusion}

Rural tourism in Serbia has begun to develop since the seventies of the twentieth century. The initial phase is characterized by uncontrolled access without clear market policy. The new millennium has entered a phase of "dedicated development". The relevant state authorities allocate adequate resources to improve the development of rural tourism in some areas.

With its natural and social resources in the area of Novi Sad is a very promising area for the development of rural tourism. With regard to the forms in the area of Novi $\mathrm{Sad}$, it is possible to develop all kinds of rural tourism.

Expectations are that rural tourism could accelerate overall economic development and prevent negative trends plaguing the rural areas (depopulation, migration to urban centers, aging population, reducing macro-economic indicators, etc.). 
Various rural areas offer the basis for further planning and action in this field. The access should be planned and selective. The program of the stay of the tourist in all areas should be planned and justified at all levels of organized tourist activities (both vertical and horizontal). A wide range of forms of tourism of special interest is a great chance for us here and it should be emphasized in the future. So, the plan of the sustainable development should be given full respect consistently. This is in the interest of both the host and the tourist coming from the developed and highly industrialized countries who have recently been interested in sojourn in the above regions.

\section{References}

Vuković, P., Arsić, S., \& Cvijanović, D. (2010). Konkurentnost ruralnih turističkih destinacija. Ekonomika poljoprivrede, 57(1), 47-60.

Vukovic, P., Kljajic, N., \& Arsic, S. (2012). Multifunctional Agriculture as an Assumption and a Condition for Rural Development in Serbia: Special Turn to Rural Tourism. International Journal of Sustainable Economies Management (IJSEM), 1(2), 24-32.

Vuković P., Mijajlović N., \& Arsenijević Ž., (2009). Rural Tourist Destination Attractiveness and Competitiveness as Conditions for Making New Brands, International Symposium on the topic "Prospect of Agriculture and Rural Areas Development", Series "Management, Economic Engineering in Agriculture and Rural Development", 9 (3), 225-228.

Cvijanović D., Vuković P. (2014). Rural Tourism in the Danube Region of the Republic of Serbia - Comparative Experiences and Development Perspectives 32. Contemporary issues of sustainable rural development: International approaches and experiences of Eastern Europe and Russia, 31-48,

Vuković, P., Cecić, N., \& Cvijanović, D. (2007). Održivi turistički razvoj ruralnih područja Srbije. Ekonomika poljoprivrede, 54(3), 369-379.

Vuković, P., Cecić, N. \& Arsić, S., (2007). Elementi marketing i menadžment strategije turističke destinacije Novi Sad, Ekonomika, 53 (5-6) 121-129.

Vuković, P., Roljević, S., \& Sarić, R. (2009). Strateška opredeljenja za multifnukcionalni koncept poljoprivrede i očuvanje životne sredine. Poljoprivredna tehnika, 34(4), 45-52.

Vuković, P., Kljajić, N., \& Roljević, S. (2009). Strateška opredeljenja razvoja turizma u procesu tranzicije u Srbiji, Ekonomika 55(3-4), 168-177.

Vuković, P., Kljajić, N., \& Arsić, S. (2012). Multifunctional Agriculture as an Assumption and a Condition for Rural Development in Serbia-Special Turn to Rural Tourism“, International Journal of Sustainable Economies Management, $1(2), 24-32$.

Cvijanović, D., Vuković, P., (2012), Uloga marketinga u turizmu Dunavskog regiona“, Institut za ekonomiku poljoprivrede, Beograd

Cvijanović D., Vuković P., (2012). Edukacija lokalnog stanovništva kao pretpostavka za razvoj ruralnog turizma u Srbiji, Agroekonomika, 53-54(53-54),73-79. 
Vuković, P., Roljević, S., \& Grujić, B. (2013). Mogućnosti za razvoj turizma zasnovanog na prirodnim i društvenim resursima u području 'Gornjeg Podunavlja'. Ekonomika, 59(3), 155-160.

A Practical Guide to Tourst Destination Management (2007), World Tourism Organization, Madrid.

Institute for nature conservation of Serbia, http://www.zzps.rs/novo/index. php?jezik=sr\&strana=zastita_prirode_zasticena_prirodna_dobra (15.6.2015)

TONS, Turistička organizacija grada Novog Sada, http://novisad.travel/(15.6.2015)

Zvanična prezentacija grada Novog Sada |Novi Sad, http://www.novisad.rs/ (15.6.2015) 
